\title{
Managing People In A Lean Environment: The Power Of Informal Controls And Effective Management Of Company Culture
}

Mary J. Gander, PhD, Winona State University, USA

\begin{abstract}
This short case at a high tech company in the Midwest, illustrates some important principles for managing people focusing more on informal, rather than formal controls. Lean Thinking advocates reducing waste, and continuously improving (Womack \& Jones, 2003). When a company shifts paradigms from traditional management to Lean management, the culture of the company transforms in many ways. Traditional, formal methods of controlling employee behavior often involve a lot of non-value-add labor and cost, at the same time, they are not effective. They are seemingly based on the attitude that employees are unprofessional, cannot develop internalized standards of behavior or understand the "big picture" of why it is in their own best interests to maintain high standards. Analysis of this incident is useful for students of Lean management, in helping them see the power of informal controls embedded in the company culture.
\end{abstract}

Keywords: Lean culture; Lean conversion; Lean management

\section{TRYTECH'S TOOL CABINET}

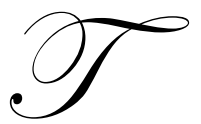

ryTech, a successful company located in the Midwest, was experiencing many of the same difficulties many other medium-sized companies were experiencing when the economy took a downturn in the early 1990's. Their products were becoming too expensive to manufacture and taking too long to ship, and there was too much waste. TryTech's CEO, Scott Sweetland, had been investigating the principles and methods of Lean management and determined that his company's biggest opportunities were internal, not external. They embarked on a Lean conversion of the company by hiring a Lean consulting firm. Everyone got involved. All employees were trained in Lean principles and methods. They worked on studying and improving processes, designs, services, plant floor layouts, implementing pull JIT production, 5-S, and preventive maintenance. Within three years the company was experiencing tremendous growth and they won the Malcolm Baldridge National Quality Award. Many people said that TryTech was the first "truly Total Quality" company to win the award.

During the first year of the transformation, a team of employees in one section of the plant floor were involved in a Kaizen project, studying key aspects of their value stream in an effort to further enhance production flow, reduce inventory, defects, and waste, and reduce cycle time. They had worked on several successful Kaizen projects and learned a great deal about their equipment, customers, products, parts and materials, and the whole value stream. Thus, they had also learned about waste and cost, and how they impacted the success and stability of TryTech. As with many companies that convert to Lean operations, employees were learning daily, seeing the bigger picture of the whole value stream, and understanding they many types of waste, as well as its relationship to costs and to their own job security and job satisfaction. The culture at TryTech was undergoing fundamental change, in attitudes, values, priorities, and norms of behavior. 
This Kaizen team noticed that a large tool cabinet which contained highly expensive, specialized tools, many of which were custom made and hard to find, was a cause of much wasted time and non-value-add activity. The cabinet door was kept shut and locked, a "guard" had authority over the cabinet, and any employee getting a tool from the cabinet had to have proper paperwork which he or she showed the guard who then opened the cabinet, and completed additional paperwork when the employee brought the tool back, in order to maintain effective control over the highly valuable inventory of tools. Even so, a couple of tools had been lost the prior year.

The team came to the conclusion that significant wasted activity could be reduced and cycle time improved, if management would agree to leave the door unlocked while the guard was in place, and they suggested a method of significantly reducing the paperwork and approvals needed. Management reacted favorably to the request, they had seen this team, as well as other teams, make a growing number of excellent improvements. In fact, management went far beyond the team's requests. They eliminated all paperwork except a simple "sign the tool out and sign the tool in" register. They removed the lock and they removed the guard. And, they even removed the door on the cabinet!

For more than a year, not a single tool was misplaced, broken, or lost. Trust reduces a lot of waste. By that time the company was growing rapidly and many new employees were being hired. Soon, tools from the cabinet were broken and missing. Management reacted by installing a door with a lock, requiring written approval to take a tool, and paper work when it was returned. They put an employee in charge of the key and of making sure the paperwork and approvals were accurate and properly filed.

\section{Questions for analysis and discussion}

1. In this incident, what was controlling employee behavior, before the process of getting tools from the cabinet was improved?

2. What was controlling employee behavior, after the process of getting tools from the cabinet was improved?

3. How would you categorize these two types of controls (extrinsic or intrinsic; formal or informal)?

4. Which type of control was more effective and why?

5. Why did tools start to be missing and broken again?

6. Why did management react the way it did to solve the problem of missing and broken tools?

7. Suggest and support a more effective approach that management could have taken in solving this problem, using Lean thinking.

\section{TEACHING NOTES}

This short incident actually occurred as stated, though the name of the company is camouflaged. It is a good example of some important concepts and issues in Lean management, including:

- Use of formal vs informal controls in managing people

- $\quad$ The important role company culture plays in influencing and maintaining employee behavior

- $\quad$ Employee involvement and ownership of improvement ideas (changes)

- The common management reaction to "go back to the old ways" when a barrier or problem occurs in the transformation (lack of constancy of purpose, Womack, 2008)

- $\quad$ The importance of effective assimilation (enculturation) of new employees

- How and why a company’s culture undergoes fundamental change during a Lean conversion

\section{Traditional Formal Management Controls to Influence Employee Behavior}

Formal Controls include both (externally applied) disciplinary systems and incentive systems. A number of researchers have articulated the types, limitations, and problems associated with formal, externally applied employee control methods. (e.g., Dickinson \& Gillette, 1993; Deming, 1986; Gander, 1994; Kohn, 1993; O’Hara, et. al., 1985; Scholtes, 1987; Katz \& Kahn, 1978; Tonkin, 2008). Deming consistently advocated allowing opportunities for intrinsic motivation in workers. 
Formal controls are often inferior to informal controls in a number of important ways:

- Not as effective in influencing employee behavior, and sustaining changes in behavior over the long run, in a wider variety of circumstances

- $\quad$ Much more costly and add no real value for the customer

- $\quad$ Add to organizational complexity and inflexibility

- $\quad$ Add wasteful activity and can result in resentment or lowered self esteem in employees

- $\quad$ Can create more work for and frustrate trustworthy employees

- With extrinsic controls, management "owns" the responsibility for appropriate behavior, not employees

If management sets rules to control employee behavior, it must also "police" to see that they are not broken, and it must have a "judicial process" to deal with infractions, and it must have a punishment and documentation process and someone to be responsible for it, and so on. All this takes labor and time, and adds to organizational complexity without adding customer value. Probably more importantly, it tends to take "ownership" of effective work behavior away from the employees themselves (Shook, 2008).

\section{Informal Controls on Employee Behavior}

Informal controls are those "inside" of the employee. For example, the employees at TryTech who were trained in Lean Thinking and had been studying and improving the company's production system, learned first-hand why and how stealing or losing or damaging an expensive tool relates to decreased productivity, decreased likelihood of satisfying customers, increased costs and waste, and, finally, to a less successful, less competitive company and less secure jobs. Such employees have internalized attitudes and values that are incompatible with misuse of the company's expensive tools. They have internalized a high standard of behavior at work for reasons they have learned themselves and understand well. As more employees at TryTech made this change, the culture of the company changed. Once higher standards of behavior have developed in a company culture, personal/professional beliefs and understandings, self-concept and peer pressure act to reinforce and maintain these higher standards of behavior. This is a powerful, omnipresent influence on employee thinking and behavior. Once such behavior becomes routine, almost unconscious, that, too, is a powerful maintainer of the behavior.

Informal controls are those "inside" the employee and "inside" the company culture:

- $\quad$ Once the standards of behavior are instilled, the cost of informal control is minimal (peer pressure selfdiscipline, routine thought process)

- $\quad$ The strength of the control is great

- $\quad$ Employees "own" the behavior

- Complexity is eliminated from the system, more flexibility results, waste and cost are reduced

\section{Why did the new culture at TryTech break down?}

When a "problem" occurs in a Lean environment, the most response should be to conduct a causal analysis, which generally involves a group of individuals using the systematic "Why? Why? Why? " inquiry. When this was later done at TryTech, by a Kaizen team, they discovered a main cause: so many new employees entered the company so fast, the culture could not assimilate them. The culture became diluted or "contaminated" so to speak. In addition, management didn't see it coming so nothing was done to prevent the breakdown. Often times managers neglect the importance of managing company culture. They do not realize the power it has to guide employee behavior, nor do they realize that it can be effectively managed.

\section{What could management have done to ensure the successful socialization of new employees into the excellent company culture that had been developing at TryTech?}

Orientation, training, assignment of mentors - all are ideas that participants analyzing the case will suggest as having potential to prevent this type of problem. This can lead to a good discussion of why managers should be 
more aware of culture, and develop skill in how to manage it effectively. To bring this home to students, their own university or company can be an example to discuss -- did the they have any formal programs or methods to socialize new people into the culture? Any "professional training program" will instill standards of quality, ethics, behavior, attitudes and values, in its students. This is in large part at the core of what it is all about to be a "professional" -- standards are adhered to even when there is no supervision, no one watching. In this regard, in a Lean company, everyone becomes a professional.

\section{The tendency of management to revert back to old ways when something goes wrong}

Often in the transformation to Lean, new ground is broken, new paths are forged-managers who managed transactions and thought their job was to make the current system work, rather than improve it, have a difficult time with the uncertainty encountered in the fundamental changes that must take place. Real leadership is needed during the conversion months and years, people who are breaking new ground need positive, visionary and supportive leaders. Individuals who have the courage to persist in practicing Lean Thinking, display what Dr. Deming often called "constancy of purpose" (Womack, 2009). When a difficulty comes up, they take it on and move forward, they do not revert back to the past. Change and learning involve taking risks, involve persisting in applying the new thinking and methods even when the going gets tough.

\section{Manage the Culture Effectively and It will Manage Employee Behavior and Attitudes}

W. Edwards Deming often said, "Quality starts at the Top" (e.g., Deming, 1986). Attitudes, priorities, and important aspects of work ethic emanate from the executive level in any organization. Behavioral norms and ways of doing one's job also depend on the particular work group and leaders in the function and department in which an employee works. Some methods of "managing the organizational culture" include:

- Leaders consistently articulate and communicate the important company's attitudes, values and priorities

- Leaders consistently embody and exhibit those same values and priorities in their own behavior, decisions, and treatment of employees and customers

- Leaders support the development of a Lean Culture in their company through implementing Lean operations and methods, regardless of whether they are a service company or organization, manufacturing, or public sector organization (e.g., Spear, 2004; Ohno, 2006; Scherkenbach, 1991)

- $\quad$ Leaders understand that new employees must successfully complete a process of being exposed to the company culture, being accepted by their co-workers, and internalizing important elements of the culture so they consistently exhibit the attitudes and values of the culture in their behavior on the job

- Leaders who are effective mentors and can role-model effective mentoring behavior, help to establish a "culture of mentoring" which is fundamental to sustaining a Lean organization (see Shook, 2008, and Ouchi, 1981)

- $\quad$ Leaders can formally assist this socialization process by:

- Screening new employees to find those who are likely to be a better "fit" for the company (this does not mean that a company should screen out individuals of diverse ethnic backgrounds, on the contrary, modern organizations should embrace diversity, but rather should consider what attitudes and behaviors help the organization sustain competitive advantage and long term success)

- Conducting well-designed orientation and training for new employees.

- Assigning each new employee to a mentor, an employee who develops a real connection with the new employee and helps them get socialized into the new culture, and may also help them learn their new job, as well as coaches them as needed, and tracks their progress

- Tracking key performance measures to monitor how well a group of new employees is becoming successfully enculturated

Leaders "create" meaning for employees. That is, how they respond to a situation will show employees how important or unimportant it is. Events they emphasize or support will also tend to convey importance or stronger meaning. Things that are measured and tracked by management will be seen as important and have stronger meaning in the company culture. Specific employee behaviors that are rewarded by individual monetary incentives will take on high priorities among employees, but also create a number of dysfunctional outcomes, 
including decreased teamwork, more internal competition, neglect of other important aspects of their work, customer dissatisfaction, and so on (E.g, Kohn 1993). Helping to create meaning and priorities of more value to the organization include:

- Invest in "celebrating" successful milestones in improving processes and system factors.

- Invest in establishing the celebration of certain traditions, employee team recognition, important improvements, supplier and customer recognitions, community and humanitarian projects, and so on, as a whole company.

- $\quad$ Company-wide sharing of success such as profit sharing or stock option programs.

\section{CONCLUSION}

A strong, well established company culture will be most effective in maintaining effective attitudes and behaviors in employees and in reducing wastefulness of more traditional employee control methods. Once established and property maintained, a strong company culture works informally and intrinsically to effectively influence employee behavior. Then new employees enter the company, especially when there are many of them entering within a relatively short amount of time, more effort must be invested in effectively socializing them into the organization's Lean culture, if Lean Thinking is to be preserved.

\section{AUTHOR INFORMATION}

Mary J. Gander, PhD, Dr. Gander has been a tenured member of the Management Department faculty at the University of Wisconsin, La Crosse, and later a full tenured professor in the Business Administration Department at Winona State University. She has served as an Interim Dean of Business, has chaired both a Business Administration Department and an MIS/OM Department. She has been author, director and major investigator on five large, successful, 3-year grant projects, each involving industry partners. Over the past 20 years, Dr. Gander has been a consultant to business and industry in applying JIT and Lean Management principles and methods, mainly in manufacturing but also in health care, insurance, publishing, and wholesale distribution companies, as well as in government and non-profit organizations. She maintains a consistent record of research and publishing. She teaches courses in Lean Operations Management, Quality Management, Strategic Management, Supply Chain Management, and Organizational Behavior. Dr. Gander has traveled and studied in many countries and has taught several times in the MBA Program at the University of International Business and Economics in Beijing, China, as well as conducted a travel study for students to Shanghai, China in 2007.

\section{REFERENCES}

1. Deming, W.E., Out of the Crisis, MIT Press, 1986.

2. Dickinson, A. and Gillette, K. A., Comparison of the Effects of Two Individual Monetary Incentive Systems on Productivity: Piece Rate Pay versus Base Pay Plus Incentives, Journal of Organizational Behavior Management, vol. 14, 3-82, 1993.

3. Gander, M., Effects of Piece Rate Incentive Pay on Quality and Productivity in a Manufacturing Company, Proceedings of The Production and Operations Management Society Annual Meeting, Washington, D.C., October, 1994

4. Haley, J. O., Authority Without Power: Law and the Japanese Paradox, Oxford University Press, 1991.

5. Katz, D. and Kahn, R. The Social Psychology of Organizations. NY: Wiley, 1978.

6. $\quad$ Kohn, A. Rethinking Rewards, Harvard Business Review, 37-49, Nov-Dec. 1993.

7. Kohn, A. Why Incentive Plans Cannot Work, Harvard Business Review, 54-63, Sept-Oct, 1993.

8. Liker, J., The Toyota Way: 14 Management Principles from the World's Greatest Manufacturer, McGraw Hill, 2003

9. Neave, Henry R. The Deming Dimension, Knoxville, TN: SPC Press, 1990.

10. O'Hara, K; Johnson, C.; and Beehr, T; Organizational Behavior Management in the Private Sector: A review of Empirical Research and Recommendations for Further Investigation, The Academy of Management Review, vol. 10, 848-864, 1985.

11. Ohno, Taiichi, Workplace Management, Mukilteo, WA: Gemba Press, 2006. 
12. Ouchi, William G. Theory Z, Addison-Wesley, 1981.

13. Savary, LM and Crawford-Mason, C., The Nun and the Bureaucrat: How they found an unlikely cure for America's sick hospitals (Chapter 16), C-M Productions, Inc, 2006.

14. Scherkenbach, W. Deming's Road to Continual Improvement, Knoxville, TN: SPC Press, 1991.

15. Scherkenbach, W. The Deming Route to Quality and Productivity, Washington D.C.: CREEPress Books, 1986.

16. Scholtes, P. An Elaboration on Deming's Teachings on Performance Appraisal, copyright Joiner Assoc. Inc., Madison, WI, 1987.

17. Shook, J., Managing to Learn: Using A3 Management to Solve Problems, Gain Agreement, Mentor, and Lead, The Lean Enterprise Institute, 2008

18. Spear, S., Learning to Lead at Toyota, Harvard Business Review, May 2004.

19. Tonkin, L., Beyond the Bucks, the Banners, and the T-Shirts: Motivation/Rewards are about Mutual Respect and Developing People, Target, (ame.org) Vol. 24, Number 3, 2008.

20. Womack, J. and Jones, D., Lean Thinking: Banish Waste and Create Wealth in Your Corporation (E2), Simon and Schuster, 2003.

21. Womack, J., “Constancy of Purpose” E-Letter, LEI, lean.org, Feb. 11, 2009. 